\title{
Selection Criteria for Meat Production Based on the Morphometry of Morada Nova Lambs: A Systematic Approach
}

Genilson Cesar Alves

UVA: Universidade Estadual Vale do Acarau

Wilder Hernando Ortiz Vega

UNINTA: Centro Universitario INTA

Robson Silveira ( $\nabla$ robsonmateus1994@hotmail.com )

Universidade Estadual Vale do Acarau https://orcid.org/0000-0003-2285-9695

Hélio Henrique Araújo Costa

UVA: Universidade Estadual Vale do Acarau

Aline Vieira Landim

UVA: Universidade Estadual Vale do Acarau

\section{Research Article}

Keywords: Animal Genetic Resources, Carcass, Genetic group, Semi-arid, Zoomometric analysis

Posted Date: June 4th, 2021

DOI: https://doi.org/10.21203/rs.3.rs-561982/v1

License: (a) This work is licensed under a Creative Commons Attribution 4.0 International License. Read Full License 


\section{Abstract}

The objective of this study was to characterize the meat production potential of Morada Nova lambs from different genetic groups using morphological and zoometric data, performance and carcass characteristics. A total of 24 non-castrated male lambs from two genetic groups were used: Morada Nova red $\left(\mathrm{MN}_{\mathrm{R}}\right)$ and Morada Nova $\mathrm{F}_{1}$ red $x$ Morada Nova white $\left(\mathrm{M}_{\mathrm{N}} \mathrm{F}_{1}\right)$ breed, with an initial mean body weight of $16.9 \pm 3.43 \mathrm{~kg}$ and an average age of four months were distributed in a completely randomized design. Evaluations of morphometric data and zoom indices, performance and carcass characteristics were measured and calculated. Univariate and multivariate techniques were used to differentiate and reduce the number of variables, to group them and then develop and validate a sheep meat production index. Only 12 differences in the 29 morphometric measurements and zoometric indices analyzed were observed $(P<0.05)$. Furthermore, only 7 of the 28 quantitative and qualitative characteristics of the carcass were greater $(P<0.05)$ in $\mathrm{M}_{\mathrm{N}} \mathrm{F}_{1}$ lambs. The yields of commercial cuts and the physical-chemical characteristics and qualitative measurements of the carcass were similar $(P>0.05)$ between the genetic groups. All groups of variables, except the cut yield, have discriminatory power $(P<0.05)$ with the highest classification percentages for body morphometry (91.3\%) and zoometric indices (95.7\%). The four identified factors, which together explain more than $85.0 \%$ of the total data variation, were renamed in the following order of importance: morpho-economic (38.5\%), morpho-productive (18.8\%), morphocommercial (17.5\%), and equilibrium (11.0\%). The heat map showed the suitability in the morphocommercial and morpho-economic factors for $\mathrm{M}_{N} \mathrm{~F}_{1}$ lambs, while the $\mathrm{M}_{N R}$ lambs showed emphasis for the equilibrium factor. Thus, the Sheep Meat Morphometric Index $\left(S_{M M I}\right)$ resulted in the following equation

$\mathrm{S}_{\mathrm{MMI}}=\frac{\mathrm{AI} \times 0.771+\mathrm{CH} \times 0.759+\mathrm{RH} \times 0.878+\mathrm{TPRI} \times 0.876+\mathrm{BI} \times 0.550+\mathrm{CW} \times 0.905}{100}$

In which: $A_{l}$ is the anamorphosis index; $C_{H}$ is chest height; $R_{H}$ is rump height; $T_{P R I}$ is the thoracic perimeter relation index; $\mathrm{B}_{\mathrm{I}}$ is body index; and $\mathrm{C}_{\mathrm{W}}$ is chest width. The application and validation of the developed index showed superiority $(P<0.001)$ for meat production in the crossed lambs. $M_{N R}$ and $M_{N} F_{1}$ lambs have high thoracic development, compact character and aptitude for meat production. Lambs crossed between genetic groups of the $\mathrm{M}_{\mathrm{N}}$ breed are another sustainable option for sheep production in drylands. It is recommended that the $S_{\mathrm{MMl}}$ be used as a tool for morpho-productive selection criteria in breeding programs in the $\mathrm{M}_{\mathrm{N}}$ breed, as well as other small native breeds.

\section{Introduction}

The Brazilian semi-arid region has traditionally raised sheep with a total of $68.5 \%$ of the national effective herd [Brazilian Institute of Geography and Statistics (IBGE, 2018)], with the potential for semi-intensive exploitation in sheep meat farming mainly using native breeds and their crosses to increase meat production (Castro et al., 2020; Silveira et al., 2021a). Among these breeds, Morada Nova $\left(\mathrm{M}_{\mathrm{N}}\right)$ is one of the main genetic resources of hair sheep in the Brazilian semi-arid region, being recognized for its 
resistance to gastrointestinal endoparasites (Ferreira et al., 2019), adaptability to the thermal environment of the semi-arid region (Leite et al., 2018; 2020), productive potential as a maternal race in terminal crossbreeding (Landim et al., 2021), fertility without seasonal influence (Moura et al., 2019), carcasses with fatty acid profiles with potential benefit to human health (Lage et al., 2020) and excellent productive potential and skin quality (Vasconcelos-Filho et al., 2021; Alencar et al., 2021).

The Brazilian Association of Sheep Breeders (Associação Brasileira de Criadores de Ovinos - ARCO) recognizes the genetic record of two genetic groups of the $M_{N}$ breed: red and white hair. These present genetic differentiation between themselves, being considered distinct genetic groups (Ferreira et al., 2014). However, there is population fragility with the native breeds due to extinction risk, low effective number of the herd and increased inbreeding rate caused by the indiscriminate introduction of exotic breeds (Nunes et al., 2020). Specifically, the creation of the MN breed is still undervalued in production systems, with the white genetic group being empirically recognized by farmers as "not adapted" to the thermal environment of the Brazilian semi-arid region, and the red genetic group for its small size. Thus, conducting a survey on the breeding pattern and meat production potential of this breed is essential to encourage the sustainable insertion of these animals in sheep production systems (Lobo, 2019).

A tool used to determine the breeding pattern is by means of body biometrics, which is performed from metric measurements on the animal's body in vivo. This simple tool is applied in commercial herds and/or in nuclei to preserve genetic resources in order to assist in zootechnical characteristic studies. With the association of these measures from different body regions, it is possible to generate zoom indices which identify the aptitude and productive potential of the animals, defining the breeding pattern and ability for commercial exploitation (Guimarães, 2018), in addition to relating these indicators to the performance and carcass characteristics. The diversity of this information requires adopting a systematic approach to explore the relationship and identify the main predictor variables for studies of this nature. Multivariate analysis techniques are useful tools for relating sets of indicators (Silveira et al., 2021b) and to develop indexes which assist in decision-making for animal selection and adaptability (de Vasconcelos et al., 2020).

To the best of our knowledge, there is no information on characterizing the potential for meat production using zoomometric measures and indices, nor are there any studies evaluating the performance using the white $M_{N}$ breed genetic group crossbred with the red $\left(M_{N R}\right)$. Therefore, this study aimed to characterize the meat production potential of $\mathrm{M}_{\mathrm{NR}}$ and $\mathrm{M}_{\mathrm{N}} \mathrm{F}_{1}$ lambs using morphological and zoometric data, performance and carcass characteristics.

\section{Material And Methods Experiment site}

The study was conducted at the Research Center for Nutrition of Small Ruminants at the Experimental Farm of the State University Vale do Acaraú (UVA), located in Sobral, Ceará, Brazil (3 36" S, 40 18" W 
and $56 \mathrm{~m}$ asl). The region's climate is Bsh (B - Dry, S - Semi-arid, low h-latitude) according to the Köppen Climate Classification (Alvares et al., 2013).

\section{Animals, experimental design and diet}

A total of 24 non-castrated male lambs from two genetic groups were used: Morada Nova red $\left(M_{N R}\right)$ and $F_{1}$ Morada Nova red $x$ Morada Nova white $\left(M_{N} F_{1}\right)$ with an average initial body weight of $16.9 \pm 3.43 \mathrm{~kg}$ and an average age of four months distributed in a completely randomized design. The lambs were fed a standard isoproteic and isoenergetic diet during the experimental period according to the nutritional requirements recommended by the National Research Council (NRC; 2007) for lambs of late maturity in the finishing phase with a predicted weight gain of $200 \mathrm{~g} \mathrm{day}^{-1}$. Water and mineral salt were supplied $a d$ libitum.

\section{Measurements and morphometric indices in vivo}

Morphometry was measured in the last week prior to slaughtering the animals with a tape measure and a biometric rod adapted according to (Bianchini et al., 2006; Araújo et al., 2014; Rezende et al., 2014). The lambs were kept in the correct upright position on a horizontal concrete floor without slope during the measurements. Thus, the withers height $\left(W_{H}\right)$, rump height $\left(R_{H}\right)$, chest height $\left(C_{H}\right)$, thoracic depth $\left(T_{D}\right)$, chest width $\left(C_{W}\right)$, body length $\left(B_{L}\right)$, and chest girth $\left(C_{G}\right)$ were measured. The morphometric measurements were combined to elaborate conformation indices, aptitudes and productive and genetic potential according to (Contreras et al.,2011; Silva-Jarquin et al., 2019; Ramos et al., 2019). The indices with their respective equations were: 1 ) Body index $\left(B_{l}\right)$ : body length divided by thoracic perimeter (longilinear animals have $B_{1}>0.90$; medium-length $0.86 \leq B_{1} \leq 0.88$; and short-lived animals $B_{1}<0.85$ ); 2) Relative body index $\left(R_{B I}\right)$ : ratio of body length to withers height; 3 ) Thoracic perimeter relation index $\left(T_{P R I}\right)$ : chest circumference divided by withers height; 4) Anamorphosis index $\left(A_{1}\right)$ : thoracic perimeter squared divided by withers height, multiplied by $100 ; 5)$ Body capacity index " 1 " $\left(\mathrm{B}_{\mathrm{Cl}}\right.$ "1"): corresponding to the quotient between weight and body length; 6) Body capacity index "2" ( $\mathrm{B}_{\mathrm{Cl}}$ "2"): corresponding to the quotient between weight and thoracic perimeter; 7$)$ Withers-rump relation index $\left(W-R_{R I}\right)$ : withers height divided by rump height; in which: values equal to 1 describe an animal with thoracic and pelvic limbs of the same height (balance); 8) Body side index $\left(\mathrm{B}_{\mathrm{SI}}\right)$ : withers height divided by body length, multiplied by 100 . This index provides an understanding of the general shape of the animal's body, meaning if it is long and leggy or short, also indicating production capacity; and 9) Thoracic body index $\left(T_{B}\right)$ : ratio given by dividing body length and withers height by withers height and chest depth, multiplied by 100 .

\section{Slaughter and carcass characteristics}

The lambs were slaughtered at approximately seven months of age. The animals were fasted on a solid diet for 16 hours and then weighed prior to slaughter. The slaughter procedure was carried out following the rules of the Industrial and Sanitary Inspection of Products of Animal Origin (RIISPOA-Regulamento 
da Inspeção Industrial e Sanitária de Produtos de Origem Animal) (Brazil, 2017). Then, the non-carcass components were eviscerated and weighed. After obtaining the carcasses, the $\mathrm{pH} 0$ hour after slaughter was measured using a portable digital pH meter (Testo 205, São Paulo, Brazil) provided with a glass electrode, calibrated with $\mathrm{pH} 7.0$ and $\mathrm{pH}$ buffer solution 4.0. The carcasses were identified and weighed to determine the hot carcass weight $\left(\mathrm{H}_{\mathrm{CW}}\right)$. The empty body weight $\left(\mathrm{E}_{\mathrm{BW}}\right)$ was determined according to Silva Sobrinho, (2001). Then, the carcasses were packed in plastic bags and sent to a cold chamber $\left(4^{\circ} \mathrm{C}\right.$ for 24 hours). After this period, the cold carcass was weighed and the $\mathrm{pH} 24$ hours after slaughter was determined. The cooling weight loss $\left.\left[\mathrm{C}_{\mathrm{WL}} \%\right)=\left(\mathrm{H}_{\mathrm{CW}}-\mathrm{C}_{\mathrm{CW}}\right) \times 100 / \mathrm{H}_{\mathrm{CW}}\right]$, in which: $\mathrm{H}_{\mathrm{CW}}=$ hot carcass weight $(\mathrm{kg})$ and $\mathrm{C}_{\mathrm{CW}}=$ cold carcass weight $(\mathrm{kg})$. The cuts and carcass composition were longitudinally sectioned using a cold saw (G Paniz SF248, Rio Grande do Sul, Brazil), and the left half carcasses were divided into six commercial cuts: leg, shoulder, rib, breast, neck, and loin. These cuts were individually weighed to determine their respective yields (\%). In addition, subcutaneous fat thickness $\left(\mathrm{S}_{\mathrm{FT}}\right)$ was measured using a 200 mm digital caliper (ZAAS-01.0013, São Paulo, Brazil) (Silva Sobrinho, 1999). Finally, the loin eye area of the Longissimus lumborum $\left(L_{L}\right)$ muscle exposed on the $12^{\text {th }}$ thoracic rib was calculated using the geometric method.

\section{Qualitative analysis of the carcass}

Conformation, finishing and evaluation of perireneal fat were determined by visually evaluating the carcass according to the methodology described by Cezar and Souza (2007). For conformation, a score of 1 was given for poor conformation to 5 as very good according to the musculature and adipose tissue deposition in relation to the skeleton. Meanwhile, finishing was classified into five categories (score $1=$ very thin and $5=$ very fat) according to the subcutaneous fat amount and distribution in the chilled carcass. A score of 1 to 3 was assigned for perirenal fat assessment according to the amount of fat in the abdominal cavity around the kidneys $(1=$ left kidney without fat cover; 2 = fully coated left kidney and the right partially; and $3=$ both are covered by a thick layer of fat).

\section{Morphometric measurements and carcass indexes}

The morphometric measurements were obtained from the carcass and were carried out as recommended by Cezar and Souza (2007). The morphometric measurements were: carcass external length $\left(C_{E L}\right)$, carcass chest girth $\left(C_{C G}\right)$, leg length $\left(L_{L}\right)$, leg girth $\left(L_{G}\right)$, arm length $\left(A_{L}\right)$, arm girth $\left(A_{G}\right)$, carcass internal length $\left(C_{\mid I}\right)$, carcass internal width $\left(C_{\mid W}\right)$. The carcass indexes and their equations were: 1$)$ Arm compactness index $\left(A_{C l}\right)$ : the quotient between the shoulder weight and the arm length; 2) Leg compactness index $\left(\mathrm{L}_{\mathrm{Cl}}\right)$ : relationship between the shank weight and the leg length; 3 ) Carcass compactness index $\left(\mathrm{C}_{\mathrm{Cl}}\right)$ : the relationship between the cold carcass weight and the internal carcass length; and 4) Carcass economic index $\left(\mathrm{C}_{\mathrm{E}}\right)$ : [(Hot carcass yield * $0.25+$ Loin eye area * $0.15+$ Leg yield * $0.1+$ Loin yield $\times 0.1+$ Subcutaneous fat thickness $\times 0.1+$ Carcass compactness index $\times 0.09+$ Conformation $\times 0.05+$ finish $\times 0.05) /($ Cooling weight loss $\times 0.05+$ age $\times 0.06)] \times 100$. 


\section{Statistical analysis}

All analyzes were processed and analyzed using the SPSS ${ }^{\circledR}$ software statistical package (Chicago, USA, 2012). The six consecutive steps are described below:

$1^{\text {st }}$ Step (Assumptions): All continuous variables met the assumptions of the analysis of variance (ANOVA) on univariate normality by the Shapiro-Wilk test $(P>0.05)$ (Shapiro et al., 1965$)$ and homoscedasticity of the variances by the Levene test (Levene, 1960).

$2^{\text {nd }}$ Step(Simple effect): The data were submitted to ANOVA followed by Tukey's means test $(P<0.05)$ for all continuous variables. The effect of genetic groups at two levels $\left(M_{N R}\right.$ and $\left.M_{N} F_{1}\right)$ was considered in the linear mode of ANOVA. The Kruskal-Wallis non-parametric analysis $(P<0.05)$ was used for qualitative carcass variables which did not present a normal distribution using the median as a measure of central tendency.

$3^{\text {rd }}$ Step(Differentiation): Canonical discriminant analysis $\left(\mathrm{C}_{\mathrm{DA}}\right)$ was used to differentiate genetic groups into 9 groups: I. body morphology, II. zoometric indices; III. carcass and muscle; IV. carcass morphometry; $V$. carcass indices; VI. carcass performance; VII. commercial cuts; VIII. cut yield; and IX. mix of variables (all variables simultaneously). The homogeneity of multivariate covariance matrices was assessed using Box's M statistical test $(P>0.05)$. The discriminant function significance was determined using the Wilks' Lambda statistic $(P<0.05)$. The main discriminating characteristics between genetic groups was identified by the highest value of the standardized coefficient of the canonical discriminating function $(r>$ $0.50)$.

$4^{\text {th }}$ Step (Identification of variables): A factor analysis $\left(\mathrm{F}_{\mathrm{A}}\right)$ was performed to identify the most relevant characteristics in meat production for the evaluated genetic groups. The analysis was initially performed for each group of characteristics in a similar way to that described in the $\mathrm{C}_{\mathrm{DA}}$. After identifying the main variables within each group of characteristics, an $\mathrm{F}_{\mathrm{A}}$ was performed to extract the factors. The number of extracted factors followed the Kaiser criterion (eigenvalues $>1$; (Kasier, 1960) with orthogonal rotation (varimax method). The factors were renamed according to the importance of the factor weights of the variables within each factor $(> \pm 0.50)$. The model adequacy was assessed using Kaiser-Meyer-Olkin statistical test $(\mathrm{KMO}=0.59)$ and the significance by Bartlett's sphericity test $(P<0.05)$.

$5^{\text {th }}$ Step(Clusters): The definition of the potential for each genetic group according to the renamed factors was performed through the hierarchical cluster analysis (HCA). Ward's method (Ward, 1963) and Euclidean distance were used to measure similarity. Next, individual eigenvalues of the $M_{N R}$ and $M_{N} F_{1}$ lambs were used in the regression method to generate the matrix. From these, the average factor score by genetic group was generated and for each renamed factor in Step 4. As a complementary analysis, the result of the grouping was plotted using a heatmap generated using the HeatMapper software program (Babicki et al., 2016). 
$6^{\text {th }}$ Step (Development of an aggregate index): The Sheep Meat Morphometric Index $\left(\mathrm{S}_{\mathrm{MMI}}\right)$ was created to facilitate identifying lamb selection to provide greater potential for meat production. The morphometric characteristics and zoom indices which integrated the index were selected according to the commonality of each characteristic in the $F_{A}$. The $S_{M M l}$ was built from the factor weights of the variables as performed by de Vasconcelos et al., (2020) using morphometric measurements, zoom indices and productive characteristics. An ANOVA between genetic groups was performed followed by a means comparison by the Tukey test $(P<0.001)$ to validate and apply the $S_{\mathrm{MMI}}$.

\section{Results}

Differences $(P<0.05)$ were observed in only 12 of the 29 variables for the body morphometric characterization and zoometric indices (Table 1). The zoometric indices $\left(B_{\mid}, T_{P R l}, A_{\mid}, B_{S \mid}, T_{B I}\right)$ classify both genetic groups as longitudinal, compact biotype, prone to meat production ability and respiratory capacity. Differences were observed $(P<0.05)$ for the anamorphosis index $\left(A_{1}\right)$ and thoracic body index $\left(T_{B I}\right)$. Regarding the carcass measurements and indexes: carcass chest girth, arm length, carcass inner width, and carcass compactness index were heavier $(P<0.05)$ in the crossbred lambs.

Regarding the productive and physico-chemical characteristics of the carcass, commercial cuts and cut yields (Table 2), only 7 of the 28 variables differed between genetic groups, observing a higher value $(P<$ $0.05)$ for $M_{N} F_{1}$ lambs. Regarding these variables, the fasting live weight, hot carcass weight, rib eye area and rib, loin and flank weights stood out. Cut yields and carcass physicochemical characteristics were similar $(P>0.05)$ between genetic groups. Qualitative characteristics (conformation, finishing and evaluation of perirenal fat) did not show an effect on genetic groups $(P<0.05)$.

The $C_{D A}$ showed that it is possible to differentiate $M_{N R}$ from $M_{N} F_{1}$ lambs from the groups of the 9 clusters (Table 3). The zoometric indices were the group of variables which had the highest percentage of correctly classified cases $\left(\mathrm{C}_{\mathrm{CC}}\right)$ in their group of origin, followed by morphometry. The mix of variables in the simultaneous assessment of all variables belonging to the discriminating groups pointed out that $\mathrm{T}_{\mathrm{B}}$, leg yield, $C_{G}$ and rib weight are the main predictor variables to differentiate purebred lambs from crossbred. The yield of the cuts in isolation did not show any power to differentiate $(P=0.092)$ the genetic groups.

The eigenvalues and commonality of the variables distributed in the factors are shown in Table 4. High commonality values $(>0.90)$ were obtained in the ranked variables of $C_{W L}, T_{P R l}, A_{l}$ and $C_{E}$, while the other variables had values $>0.70$. The first four factors explained $85.90 \%$ of the total variation in the data, in which the first factor retained $38.5 \%$ of the total variance, and constituted the variables with the highest factor load, being renamed morpho-economic. There was a positive association between $C_{C}, L_{E A}, R_{H}, C_{H}$, $T_{D}, C_{W}, A_{l}$ and $C_{E}$, but negative with $C_{W L}$. Higher coefficients in the morpho-productive factor were obtained by $\mathrm{C}_{\mathrm{Y}}, \mathrm{C}_{\mathrm{WL}}$ and $\mathrm{T}_{\mathrm{PR}}$, with $18.8 \%$ of the explained variance. The factor associated with the commercial characterization was composed of two variables with greater load (Leg Y. and $\left.B_{\mid}\right)$. Finally, the 
equilibrium factor was given by the list of variables which met the analysis assumptions $(>0.5)$, and that it was not possible to allocate these variables in the first three factors due to their compared low factor load.

The heat map (Figure 1) demonstrated the dynamics of the genetic groups based on the four factors extracted, thus revealing the productive potential of each group, in which the $M_{N} F_{1}$ lambs showed aptitude in the morpho-commercial and morpho-economic aspects (positive value of $Z$-scores) and $M_{N R}$ showed a high association for the balance factor. There was also the formation of two clusters: (i) morpho -economic and morpho-commercial; and (ii) morpho-productive and equilibrium.

The $S_{M M l}$ resulted in the following equation:

\section{$S_{M M I}=\frac{\mathrm{Al} \times 0.771+\mathrm{CH} \times 0.759+\mathrm{RH} \times 0.878+\mathrm{TPRI} \times 0.876+\mathrm{BI} \times 0.550+\mathrm{CW} \times 0.905}{100}$}

The application and validation of the $\mathrm{S}_{\mathrm{MMI}}$ is shown in Figure 2, in which crossbred lambs presented greater $(P<0.001)$ potential for meat production.

\section{Discussion}

The morpho-functional and productive characterization of the $\mathrm{M}_{\mathrm{N}}$ breed is non-existent, since the morphological evaluation is limited to considerations about breeding pattern and is only used in promotional events, fairs and exhibitions organized by breeders' associations. This study assesses the productive potential of the $\mathrm{M}_{\mathrm{N}}$ breed through morphometric, zoometric, productive data and carcass characteristics using a systematic approach with successive multivariate techniques for different objectives.

Our main findings were: $(i)$ zoometric analyzes show the capacity for morpho-productive classification of lambs from the two genetic groups of the $\mathrm{M}_{\mathrm{N}}$ breed; (ii) the zoometric indices and body morphometry are the main factors responsible for differentiation between the genetic groups evaluated in the study; and (iii) the $S_{M M l}$ has potential in the area of selection criteria for conservation programs and genetic improvement of small native sheep breeds.

The morphological indices used in this study were able to characterize the phenotypic and production potential of $M_{N}$ lambs using the $T_{P R l}, A_{1}, B_{C l}$ " 1 " and $B_{C l}$ " 2 " variables, enabling the classification of breeding groups in high thoracic development, ability to produce meat, weight gain, feeding efficiency and breathing capacity, infusing greater breed rusticity and adaptability for both genetic groups. These characteristics are in agreement with other studies which evaluated adaptability and productive potential of the $M_{N}$ breed, especially the red variety which has greater potential for meat production (Melo et al., 2018; Rezende et al., 2018; Leite et al., 2020), in addition to breaking paradigms about the low adaptability of white $M_{N}$ to the semi-arid environment, as already reported by Leite et al., $(2018 ; 2020)$. 
We emphasize that the breathing capacity of the $M_{N}$ breed is an important adaptive characteristic, since the main mechanisms of heat dissipation during the hottest periods of the day are through transferring sensitive and latent heat through the respiratory tract as observed by (Fonsêca et al., 2019), and in studies of biothermic rhythmicity (Façanha et al., 2020) and caloric management (Ferreira et al., 2020) in native breeds of small ruminants.

The superiority observed in some morphometric and productive characteristics in crossbred lambs are justified by the fact that this crossbreed brought together intrinsic characteristics of the white group, meaning that we still observe the result of the heterosis process and complementarity of characteristics between genetic groups, even within the same breed. This is mainly because the $M_{N W}$ breed is larger when compared to the $M_{N R}$ (Nunes et al., 2020). Therefore, it is inferred that the crossing between the genetic groups of the $M_{N}$ breed is another alternative to increase the carcass weight resulting in greater cuts, especially noble ones (rib, loin and breast), but with similar cut yields indicating proportionality between carcass and non-carcass components within the two genetic groups. This result may be a peculiar characteristic of using the $\mathrm{M}_{\mathrm{N}}$ breed in crossbreedings, since Landim et al. (2021) observed similarities between the cut yields in pure $\mathrm{M}_{\mathrm{N}}$ lambs when compared to crossbred Rabo Largo $\times \mathrm{M}_{\mathrm{N}}$ and Santa Inês $\times \mathrm{M}_{\mathrm{N}}$ lambs.

The thoracic body index developed a priori was fundamental for the survey of phenotypic diversity between the genetic groups. This is because there were combinations of morphometric measurements which express high responses with the profile and productive aptitude of a certain animal $\left(B_{L}, W_{H}\right.$ and $\left.T_{D}\right)$ for its development. Studies indicate the great importance of the $T_{D}$ measurement due to the close relationship with digestive capacity and rusticity (Santos, 2019).

The direct relationship between $\mathrm{S}_{\mathrm{T}}$ and $\mathrm{C}_{\mathrm{WL}}$ (Table 2) is associated with the carcass quality during the final post-slaughter process, since the cover fat has the main objective to act as a thermal insulator in cooling the carcass, thus providing less loss of weight during the maturation process (Nascimento et al., 2018; Landim et al., 2021). However, $S_{T}$ was not sufficient to maintain thermal insulation for the evaluated genetic groups, exceeding the extremity considered adequate $\left(\mathrm{C}_{\mathrm{WL}}<7 \%\right.$; Oliveira et al., 2017).

The discrimination in only one canonical discriminating function (Table 3 ) for the nine selected groups is explained because the genetic groups (white and red) belong to the same breed, which reduced the discriminatory variance shared between the genetic groups. Even the cut yields do not have an isolated capacity to discriminate genetic groups, which is justified by the similarity between yields (Table 2). The shank yield showed discriminatory power between the genetic groups when all variables were simultaneously analyzed. However, this characteristic acted in a complementary way to the others $\left(T_{B}, C_{G}\right.$ and rib weight) to classify $87.0 \%$ of the lambs in their group of origin. It is emphasized that adopting the mix of variables is important to identify the main predictor variables for inclusion in genetic breeding programs for native breeds, especially small breeds due to the lack of research. 
The higher classification rates observed when the zoometric indices and body morphometry were partially analyzed are justified by the higher values in the characteristics related to the thoracic part and the height of the crossbred lambs (Tables 1 and 2), which infer in the efficiency response from the productive point of view, i.e. the ability to gain weight and intake dry matter, which justifies the higher performance of these animals. In contrast, the lowest rates were observed in carcass performance and indexes, as the effect of crossbreeding between genetic groups did not influence most carcass variables (Melo et al., 2018; Ramos et al., 2019). The discrimination of the thoracic perimeter when evaluating the carcass morphometry is explained because this characteristic is a predictor of live weight at slaughter (Castro et al., 2012), for which both variables were higher in $\mathrm{M}_{N} \mathrm{~F}_{1}$ lambs.

In this study, the potential for meat production was assessed by factor analysis, in which the characteristics linearly associated with each other were distributed through their respective loads, making it possible to compose factors with biological and economic interpretation. The first factor grouped a larger number of variables including those which indirectly affect the final carcass characteristics, and therefore acted in the economic scope of meat production. This factor also pointed out that $\mathrm{C}_{\mathrm{WL}}$ is the single factor which most compromises the economic index, since losses due to cooling interfere with the carcass weight and quality, and consequently reduce its price. For (Landim et al., 2017; 2021), an alternative to increase $\mathrm{C}_{\mathrm{WL}}$ is the use of the Rabo Largo breed in terminal crossbreeding.

The $\mathrm{C}_{\mathrm{El}}$ inferred greater explanatory power due to the four factors extracted, in addition to having a high correlation with the $A_{1}$, which is considered an important indicator of meat production (Sabbioni et al., 2016). Therefore, if there is selection in the $M_{N}$ breed for this morphological index, there will indirectly be a positive influence on the economic aspect. Considering the variables of greatest importance and association within the first factor, it is observed that it is possible to carry out sheep selection through measurements and zoometric indices, indirectly resulting in the carcass traits, which in principle would only be analyzed after slaughter.

The second factor associated characteristics which exert great influence on the productive potential of the $M_{N}$ breed. It is possible to predetermine the digestive capacity and weight gain of a given animal using $T_{P R I}$ (Nunes et al., 2020), while $C_{Y}$ can be used in sheep farming in response to the relative percentage of meat to be marketed, as lambs generally have high yields and small variations between biotypes (Oliveira et al., 2018).

The factor associated with commercial characterization, which in turn is directly related to the animal's production capacity, and consequently greater body and carcass weight, has a direct influence with LegY, as this variable has the greatest quantitative representation of a sheep carcass (McManus et al.,2008; Trindade et al., 2018). The chest height indicates the stature of the animal, and it is recommended to raise small sheep for the Caatinga biome since the availability of food during the dry period of the year is mostly located in herbaceous extract (Nunes et al., 2020). In addition, animals with a compact profile and small to medium body structure should be chosen if the breeder intends to raise animals for meat production with a high capacity for weight gain (Ramos et al., 2019). 
The grouping plotted on the heat map clarified the specificities for meat production of the genetic groups. $\mathrm{M}_{\mathrm{N}} \mathrm{F}_{1}$ lambs presented superiority in the productive, commercial and economic aspects, while the $M_{N R}$ lambs were balanced. Moreover, Issakowicz et al. (2016) report that the lower meat production potential for the $M_{N R}$ breed when compared to other native sheep breeds is related to the small size of this breed group; however, morpho-productive characterizations are useful approaches to circumvent this limitation, as they identify the main characteristics related to the productive potential and use them as a selection criterion. The cluster formed by the morpho-economic and morpho-commercial factors is justified by their direct relationship between factors, while the balance was related to the morpho-productive factor, especially with emphasis on the crossbred lambs due to their greater production when compared to the purebred lambs.

The $S_{M M l}$ suggests that sheep obtained by crossbreeding the white and red genetic groups of the $M_{N}$ breed have a greater potential for meat production when compared with $\mathrm{M}_{\mathrm{NR}}$ lambs, demonstrating the importance of the white genetic group participating in terminal crossbreeding. Finally, this work identified predictive morphological parameters for meat production with the creation of an aggregate index obtained from the variables with greater participation in the multivariate analysis. This index presents itself as an early and practical selection criterion for meat production in native lambs, and can be used in breeding programs for sheep and by farmers, since biometrics is a simple and easy tool to perform. It is also expected to contribute to the recovery process of the $\mathrm{MN}$ white breed variety, as its use has been shown to be favorable in sheep meat production.

\section{Conclusions}

$\mathrm{M}_{N} \mathrm{~V}$ and $\mathrm{M}_{N} \mathrm{~F}_{1}$ lambs present high thoracic development, compact character and aptitude for meat production. Traits such as $\mathrm{T}_{\mathrm{B}}$, Leg $\mathrm{Y}_{\text {., }} \mathrm{C}_{\mathrm{G}}$ and rib weight were generally the most important for differentiating the genetic groups of the $\mathrm{M}_{N}$ breed. The successive adoption of multivariate techniques demonstrated greater potential for meat production for $\mathrm{M}_{N} \mathrm{~F}_{1}$ lambs, with this crossbreeding being another alternative to increase sustainable sheep production in the Brazilian semi-arid region. It is recommended that $M_{M l}$ be used as a tool for morpho-productive selection criteria in $M_{N}$ breeding programs, as well as for other small native breeds.

\section{Declarations}

\section{Conflict of interests}

None

\section{Declaration of animal rights}

All clinical procedures and examines were approved by the Ethical Committee Use Animals from State University of Acaraú Valley (Protocol nº 002.10.020.UVA.504.02.). 


\section{Authors' contributions}

Conceptualization: [Genilson Cesar Alves], [Aline Vieira Landim], [Wilder Hernando Ortiz Vega] [Hélio Henrique Araújo Costa]; Methodology: [Wilder Hernando Ortiz Vega] [Aline Vieira Landim]; Statistical analysis: [Robson Mateus Freitas Silveira], [Wilder Hernando Ortiz Vega]; Writing - preparing the original draft: [Genilson Cesar Alves]; Writing - review and editing; [Robson Mateus Freitas Silveira], [Wilder Hernando Ortiz Vega] [Aline Vieira Landim]; Supervision: [Aline Vieira Landim].

\section{Consent to publish}

The authors state that all human participants in the research provided consent for the publication of the data.

\section{Data availability}

Data will be made available on request

\section{Acknowledgments}

The Fundação Cearense de Apoio ao Desenvolvimento Científico e Tecnológico (FUNCAP)

\section{Financial support}

The Fundação Cearense de Apoio ao Desenvolvimento Científico e Tecnológico (FUNCAP) - Research Productivity Scholarship Program, Bolsa de Produtividade em Pesquisa, Estímulo à Interiorização e a Inovação Tecnológica - BPI02/2020.

\section{References}

1. Alencar, R.T., Vega, W.H.O., Silva, L.N.C., Costa, H.E.A., Parente, M.O.M., Lima, L.D., Landim, A. V., 2021. Changes on the physicochemical and fatty acid profile of meat induced by inclusion of biscuit bran in lamb diet. Anais da academia brasileira de ciências (In prelo)

2. Alvares, C.A., Stape, J.L., Sentelhas, P.C., De Moraes Gonçalves, J.L., Sparovek, G., 2013. Köppen's climate classification map for Brazil. Meteorol. Zeitschrift 22, 711-728. https://doi.org/10.1127/0941-2948/2013/0507

3. Araújo, A.A. de O., Farias, L.A., Biagiotti, D., Bolzani, G.J., Ferreira, C., 2014. Pelvimetry pig strains Agroceres and DanBred. Revista Brasileira de Ciência Veterinária 21, 262-267.

4. Babicki, S., Arndt, D., Marcu, A., Liang, Y., Grant, J.R., Maciejewski, A., Wishart, D.S., 2016. Heatmapper: web-enabled heat mapping for all. Nucleic Acids Res. 44, W147-W153. https://doi.org/10.1093/nar/gkw419

5. Bianchini, E., McManus, C., Lucci, C.M., Fernandes, M.C.B., Prescott, E., Mariante, A. da S., Egito, A.A. do, 2006. Características corporais associadas com a adaptação ao calor em bovinos naturalizados 
brasileiros. Pesqui. Agropecuária Bras. 41, 1443-1448. https://doi.org/10.1590/s0100204x2006000900014

6. Brasil. Ministério da Agricultura Pecuária e Abastecimento. 2017. Decreto n 9.013 , de 29 de março de 2017. Regulamenta a inspeção industrial e sanitária de produtos de origem animal, que disciplina a fiscalização e a inspeção industrial e sanitária de produtos de origem animal, Brasília-DF.

7. Castro, M.S.M., Vasconcelos, A.M. de, Santos, V.O. dos, Lopes, A.K.C., Farias, M.R.S. de, Lima, F.R.G., Rogério, M.C.P., Ferreira, J., Silveira, R.M.F., 2020. Thermoregulatory capacity of Santa Inês hair ewes of different genotypes associated with coat colors raised in a hot environment. J. Appl. Anim. Welf. Sci. 0, 1-11. https://doi.org/10.1080/10888705.2020.1819808

8. Castro, F.A.B. de, Ribeiro, E.L. de A., Koritiaki, N.A., Mizubuti, I.Y., Silva, L. das D.F. da, Pereira, E.S., Pinto, A.P., Constantino, C., Junior, F.F., 2012. Performance from birth to weaning of Santa Inês lambs born to ewes fed different levels of energy. Semina, 3379-3388. https://doi.org/10.5433/16790359.2012v33Supl2p3379

9. Cezar, M.F., Souza, W.H., 2007. Carcaças ovinas e caprinas: obtenção, avaliação e classificação., Agropecuária Tropical. Uberaba.

10. Contreras, G., Chirinos, Z., Zambrano, S., Molero, E., Páez, A., 2011. Caracterización morfológica e índices zoométricos de vacas Criollo Limonero de venezuela. Revista de la facultad de agronomia universidad de zulia, 29, 91-103.

11. de Vasconcelos, A.M., de Carvalho, J.F., de Albuquerque, C.C., Façanha, D.A.E., Vega, W.H.O., Silveira, R.M.F., Ferreira, J., 2020. Development of an animal adaptability index: Application for dairy cows. J. Therm. Biol. 89. https://doi.org/10.1016/j.jtherbio.2020.102543

12. Façanha, D.A.E., Ferreira, J., Silveira, R.M.F., Nunes, T.L., Oliveira, M.G.C. de, Sousa, J.E.R. de, Paula, V.V. de, 2020. Are locally adapted goats able to recover homeothermy, acid-base and electrolyte equilibrium in a semi-arid region? 90. https://doi.org/10.1016/j.jtherbio.2020.102593

13. Ferreira, J. B., Sotomaior, C. S., Bezerra, A. C. D. S., da Silva, W. E., Leite, J. H. G. M., de Sousa, J. E. R., de Fátima França Biz, J., \& Façanha, D. A. E. (2019). Sensitivity and specificity of the FAMACHAC system in tropical hair sheep. Tropical Animal Health and Production, 51(6), 1767-1771. https://doi.org/10.1007/s11250-019-01861-x

14. Ferreira, J., Silveira, R.M.F., de Sousa, J.E.R., Façanha, D.A.E., 2020. Locally adapted goats efficiently gain and lose heat in an equatorial semi-arid environment. Int. J. Biometeorol. 64, 1777-1782. https://doi.org/10.1007/s00484-020-01959-0

15. Ferreira, J.S.B., Paiva, S.R., Silva, E.C., McManus, C.M., Caetano, A.R., Façanha, D.A.E., de Sousa, M.A.N., 2014. Genetic diversity and population structure of different varieties of Morada Nova hair sheep from Brazil. Genet. Mol. Res. 13, 2480-2490. https://doi.org/10.4238/2014.April.3.20

16. Fonsêca, V.F.C., Saraiva, E.P., Maia, A.S.C., de Melo Costa, C.C., dos Santos, S.G.C.G., Morais, L.K.C., Fuller, A., Chiquitelli Neto, M., 2019. Training sheep for indirect calorimetry trials. Small Rumin. Res. 177, 36-43. https://doi.org/10.1016/j.smallrumres.2019.06.010 
17. Guimarães, J. de O., 2018. Utilização Da Morfometria Geométrica Na Caracterização Racial E Produtiva De Ovinos Morada Nova, Santa Inês , Somalis e Dorper. Universidade Estadual do Sudoeste da Bahia.

18. IBGE / Censo Agro 2017 / Home. (2017). Censo Agropecuário 2017. https://censos.ibge.gov.br/agro/2017/

19. Issakowicz, J., Issakowicz, A.C.K.S., Bueno, M.S., da Costa, R.L.D., Katiki, L.M., Geraldo, A.T., Abdalla, A.L., McManus, C., Louvandini, H., 2016. Parasitic infection, reproductive and productive performance from Santa Inês and Morada Nova ewes. Small Rumin. Res. 136, 96-103. https://doi.org/10.1016/j.smallrumres.2016.01.015

20. Kasier, H.F., 1960. The application of electronic computers to factor analysis. Educ. Psychol. Meas. $\mathrm{XX}, 141-151$.

21. Lage, R.R.P., Vega, W.H.O., Costa, H.H.A., Costa, A.C., Sousa, L.C.O., Lima, L.D., Landim, A. V., 2020. Effect of breed on meat quality and global acceptance of native lambs and their crosses. South African J. Anim. Sci. 50, 150-160. https://doi.org/10.4314/sajas.v50i1.16

22. Landim, A.V., Roriz, N.D., Vega, W.H.O., Costa, H.H. A., Sousa, L.C.O., Alves, G.C., Ferreira, J. B., Silveira, R.M.F., 2021. Sheep meat production in drylands: use of crosses between native breeds. Small Ruminant Research.(In prelo)

23. Landim, A.V., Costa, H.H.A., Carvalho, F.C., Costa, A.C., Alencar, R.T., Silva, L.N.C., Gomes, J.S., Batista, A.S.M., Miyagi, E.S., Lima, L.D., 2017. Desempenho produtivo e características de carcaça de cordeiros Rabo Largo puro e cruzados com Santa Inês [ 1267-1274.

24. Leite, J.H.G.M., Da Silva, R.G., Asensio, L.A.B., de Sousa, J.E.R., da Silva, W.S.T., da Silva, W.E., Façanha, D.A.E., 2020. Coat color and morphological hair traits influence on the mechanisms related to the heat tolerance in hair sheep. Int. J. Biometeorol. 64, 2185-2194.

https://doi.org/10.1007/s00484-020-02014-8

25. Leite, J.H.G.M., Da Silva, R.G., da Silva, W.S.T., da Silva, W.E., Paiva, R.D.M., Sousa, J.E.R., Asensio, L.A.B., Façanha, D.A.E., 2018. Locally adapted Brazilian ewes with different coat colors maintain homeothermy during the year in an equatorial semiarid environment. Int. J. Biometeorol. 62, 16351644. https://doi.org/10.1007/s00484-018-1563-x

26. Levene et al., 1960. In Contributions to Probability and Statistics: Essays in Honor of Harold Hotelling (et al.), Stanford University Press, pp. 278-292

27. Lobo, R.N.B., 2019. Opportunities for investment into small ruminant breeding programmes in Brazil. J. Anim. Breed. Genet. 136, 313-318. https://doi.org/10.1111/jbg.12396

28. McManus, C.M., Santos, S.A., da Silva, J.A., Louvandini, H., de Abreu, U.G.P., Sereno, J.R.B., Silva, A. da M., 2008. Body indices for the pantaneiro horse. Brazilian J. Vet. Res. Anim. Sci. 45, 362-370. https://doi.org/10.11606/issn.1678-4456.bjvras.2008.26677

29. Melo, B.A. de, Nascimento, I. de M., dos Santos, L.T.A., de Lima, L.G., de Araújo, F.C.T., Rios, R.R.S., Couto, A. de G., Fraga, A.B., 2018. Body morphometric measurements in murrah crossbred buffaloes 
(Bubalus bubalis). J. Appl. Anim. Res. 46, 1307-1312.

https://doi.org/10.1080/09712119.2018.1502669

30. Moura, A.B.B., Brandão, F.Z., Esteves, S.N., Nunes de Souza, G., Fonseca, J.F. da, Pantoja, M.H.A., Romanello, N., Botta, D., Giro, A., Garcia, A.R., 2019. Differences in the thermal sensitivity and seminal quality of distinct ovine genotypes raised in tropical conditions. Theriogenology $123,123-131$. https://doi.org/10.1016/j.theriogenology.2018.09.037

31. Nascimento, U.F.S., Santos, G.R. de A., Azevedo, C.S., Macedo, F.D.A.F., Gonçalves, T.R., Bomfim, L.E. de L.M., Farias, J.S., Santos, A.D.F., 2018. Performance and carcass characteristics of lambs $1 \frac{1}{2}$ Dorper $+1 / 2$ Santa Inês , slaughtered with different thicknesses of subcutaneous fat. Rev. Bras. Saúde e Produção Anim. 19, 125-135.

32. NRC, 2007. Requirements of Small Ruminants: Sheep, Goats, Cervids, and New World Camelids, 1 st ed. National academy press, Washington. https://doi.org/10.17226/11654

33. Nunes, S.F., Ferreira, J., Silveira, R.M.F., Sales, D.C., de Sousa, J.E.R., Paiva, S.R., Façanha, D.A.E., 2020. Morphometric characterization and zoometric indices of white Morada Nova breed: The first step for conservation. Small Rumin. Res. 192, 106178. https://doi.org/10.1016/j.smallrumres.2020.106178

34. Oliveira, F.G., Sousa, W.H., Cartaxo, F.Q., Cunha, M. das G.G., Ramos, J.P. de F., Cezar, M.F., Menezes, L.M. de, Oliveira, A.B., 2018. Carcass characteristics of Santa Ines sheep with different biotypes and slaughtering weights. Rev. Bras. Saúde e Produção Anim. 19, 347-359.

https://doi.org/10.1590/s1519-99402018000300011

35. Oliveira, J.P.F. de, Ferreira, M. de A., de Freitas, A.P.D., Urbano, S.A., da Silva, Á.E.M., 2017. Características de carcaça de ovinos Santa Inês alimentados com mazoferm substituindo o farelo de soja. Universidade Estadual Vale do Acaraú. Rev. Cienc. Agron. 48, 708-715. https://doi.org/10.5935/1806-6690.20170082

36. Ramos, I.O., de Rezende, M.P.G., Carneiro, P.L.S., de Souza, J.C., Sereno, J.R., Bozzi, R., Malhado, C.H.M., 2019. Body conformation of Santa Inês, Texel and Suffolk ewes raised in the Brazilian Pantanal. Small Rumin. Res. 172, 42-47. https://doi.org/10.1016/j.smallrumres.2019.01.011

37. Rezende, M.P.G. de, de Souza, J.C., Carneiro, P.L.S., Bozzi, R., Jardim, R.J.D., Malhado, C.H.M., 2018. Morphofunctional diversity of equine of varied genetic compositions raised in the Pantanal biome of Brazil. Trop. Anim. Health Prod. 50, 1033-1040. https://doi.org/10.1007/s11250-018-1527-5

38. Rezende, M.P.G. de, Luz, D.F., Ramires, G.G., de Oliveira, N.M., Barbosa Filho, J.A., de Oliveira, M.V.M., 2014. Caracterização zoométrica de novilhas remanescentes da raça Pantaneira. Cienc. Rural 44, 706-709. https://doi.org/10.1590/S0103-84782014000400022

39. Sabbioni, A., Beretti, V., Righi, F., Superchi, P., 2016. Allometric coefficients for body measures and morphometric indexes in a meat-type sheep breed. Small Rumin. Res. 144, 248-254. https://doi.org/10.1016/j.smallrumres.2016.10.005

40. Santos, L.T.A. dos, 2019. Caracterização morfométrica de ovinos da raça Bergamácia Brasileira. Universidade Federal de Alagoas. 
41. Shapiro, S.S., Wilk, M.B., Laboratories, B.T., 1965. An analysis of variance test for normality ( complete samples ). Biometrika 52, 591-611

42. Silva-Jarquin, J.C., Román-Ponce, S.I., Durán-Aguilar, M., Vera-ávila, H.R., Cambrón-Sandoval, V.H., Andrade-Montemayor, H.M., 2019. Morphostructural characterization of the black creole goat raised in central Mexico, a currently threatened zoogenetic resource. Animals 9. https://doi.org/10.3390/ani9070459

43. Silva Sobrinho, A.G., 2001. Criação de ovinos. Jaboticabal: Funep. 302.

44. Silva Sobrinho, A.G, 1999. Body composition and characteristics of carcass from lambs of different genotypes and ages at slaughter. $54 \mathrm{f}$

45. Silveira, R.M.F, Vasconcelos, A. M., Silva, J. V. da, Vega, W. H. O, Toro-Mujica, P, Ferreira, J. (2021a). Typification, characterization and differentiation of sheep production systems in the Brazilian semiarid region. NJAS - Wageningen Journal of Life Sciences (In prelo).

46. Silveira, R. M.F., Ferreira, J., Busanello, M., Maria de Vasconcelos, A., Jannuzzi Valente, F. L., \& Evangelista Façanha, D. A. (2021). Relationship between thermal environment and morphophysiological, performance and carcass traits of Brahman bulls raised on tropical pasture: A canonical approach to a set of indicators. Journal of Thermal Biology, 96. https://doi.org/10.1016/j.jtherbio.2020.102814

47. Trindade, T.F. de M., Difante, G. dos S., Neto, J.V.E., Fernandes, L.S., Araújo, I.M.M. de, Véras, E.L. de L., Costa, M.G., Silva, M.G. da T., Medeiros, M.C., 2018. Biometry and carcass characteristics of lambs supplemented in tropical grass pastures during the dry season. Biosci. J. 172-179. https://doi.org/10.14393/bj-v34n1a2018-36781

48. Vasconcelos-Filho, P. de T., Costa, H.H.A., Vega, W.H.O., Sousa, L.C.O., Parente, M.O.M., Landim, A. V., 2021. Effects of dietary energy content and source using by-products on carcass and meat quality traits of cull ewes. Animal 15, 100035. https://doi.org/10.1016/j.animal.2020.100035

\section{Tables}

\section{Table 1}

Mean and standard deviation of measurements and morphometric indices in vivo and in the carcass of the Morada Nova red breed $\left(\mathrm{M}_{N R}\right)$ lambs and crossbred with the white $\left(\mathrm{M}_{N} \mathrm{~F}_{1}\right)$ 


\begin{tabular}{|c|c|c|c|}
\hline \multirow[t]{2}{*}{ Traits } & \multicolumn{2}{|c|}{ Genetic groups } & \multirow[t]{2}{*}{$P$-Value } \\
\hline & $M_{N R}$ & $\mathrm{M}_{\mathrm{N}} \mathrm{F}_{1}$ & \\
\hline Slaughter weight & $26.3 \pm 4.0^{b}$ & $30.7 \pm 3.9^{a}$ & $=0.0016$ \\
\hline \multicolumn{4}{|l|}{ Morphometry in vivo (cm) } \\
\hline Withers height $\left(\mathrm{W}_{\mathrm{H}}\right)$ & $58.2 \pm 4.7$ & $61.3 \pm 3.0$ & $=0.067$ \\
\hline Rump height $\left(\mathrm{R}_{\mathrm{H}}\right)$ & $58.4 \pm 4.2^{b}$ & $62.8 \pm 3.4^{a}$ & $=0.013$ \\
\hline Chest height $\left(\mathrm{C}_{\mathrm{H}}\right)$ & $28.5 \pm 1.6^{b}$ & $31.1 \pm 1.7^{\mathrm{a}}$ & $<0.001$ \\
\hline Thoracic depth $\left(T_{D}\right)$ & $29.7 \pm 3.9$ & $30.2 \pm 1.6$ & $=0.730$ \\
\hline Chest width $\left(\mathrm{C}_{\mathrm{W}}\right)$ & $16.1 \pm 1.2^{b}$ & $17.5 \pm 1.0^{a}$ & $=0.010$ \\
\hline Body length $\left(B_{L}\right)$ & $64.4 \pm 2.8^{b}$ & $67.3 \pm 2.9^{a}$ & $=0.025$ \\
\hline Chest girth $\left(\mathrm{C}_{\mathrm{G}}\right)$ & $67.7 \pm 4.2^{b}$ & $72.5 \pm 2.9^{a}$ & $=0.004$ \\
\hline \multicolumn{4}{|l|}{ Zoometric index } \\
\hline Body index $\left(\mathrm{B}_{\mathrm{I}}\right)$ & $94.7 \pm 5.0$ & $93.2 \pm 2.0$ & $=0.399$ \\
\hline Relative body index $\left(\mathrm{R}_{\mathrm{BI}}\right)$ & $110.5 \pm 6.0$ & $110.2 \pm 2.9$ & $=0.896$ \\
\hline Thoracic perimeter relation index $\left(T_{\mathrm{PRI}}\right)$ & $116.6 \pm 5.1$ & $118.1 \pm 3.7$ & $=0.465$ \\
\hline Anamorphosis index $\left(A_{1}\right)$ & $79.2 \pm 5.9^{b}$ & $85.9 \pm 4.7^{a}$ & $=0.012$ \\
\hline Body capacity index "1" ( $\left.\mathrm{B}_{\mathrm{Cl}} " 1 "\right)$ & $0.41 \pm 0.05$ & $0.45 \pm 0.04$ & $=0.052$ \\
\hline Body capacity index "2" ( $\mathrm{B}_{\mathrm{Cl}}{ }^{\text {"2") }}$ & $0.38 \pm 0.04$ & $0.42 \pm 0.03$ & $=0.052$ \\
\hline Withers-rump relation index $\left(\mathrm{W}-\mathrm{R}_{\mathrm{RI}}\right)$ & $0.99 \pm 0.02$ & $0.97 \pm 0.03$ & $=0.112$ \\
\hline Body side index $\left(\mathrm{B}_{\mathrm{SI}}\right)$ & $90.7 \pm 5.1$ & $90.78 \pm 2.4$ & $=0.982$ \\
\hline Thoracic body index $\left(T_{B I}\right)$ & $56.1 \pm 2.2^{a}$ & $52.4 \pm 2.1^{b}$ & $=0.002$ \\
\hline \multicolumn{4}{|l|}{ Morphometric (cm) and Carcass e index } \\
\hline Carcass external length $\left(C_{E L}\right)$ & $53.0 \pm 2.9$ & $53.1 \pm 3.6$ & $=0.921$ \\
\hline Carcass chest girth $\left(\mathrm{C}_{\mathrm{CG}}\right)$ & $62.5 \pm 4.1^{b}$ & $67.0 \pm 2.9^{a}$ & $=0.013$ \\
\hline Leg length $\left(L_{L}\right)$ & $27.6 \pm 2.4$ & $30.3 \pm 3.7$ & $=0.072$ \\
\hline Leg girth $\left(L_{G}\right)$ & $33.0 \pm 2.2$ & $34.0 \pm 3.6$ & $=0.473$ \\
\hline
\end{tabular}




\begin{tabular}{|llll|}
\hline Arm length $\left(\mathrm{A}_{\mathrm{L}}\right)$ & $23.4 \pm 2.1^{\mathrm{b}}$ & $26.0 \pm 2.7^{\mathrm{a}}$ & $=0.031$ \\
\hline Arm girth $\left(\mathrm{A}_{\mathrm{G}}\right)$ & $18.5 \pm 1.7$ & $17.3 \pm 3.2$ & $=0.315$ \\
\hline Carcass internal length $\left(\mathrm{C}_{\mathrm{IL}}\right)$ & $42.5 \pm 3.9$ & $42.1 \pm 6.5$ & $=0.854$ \\
\hline Carcass internal width $\left(\mathrm{C}_{\mathrm{IW}}\right)$ & $17.4 \pm 2.4^{\mathrm{b}}$ & $19.3 \pm 1.3^{\mathrm{a}}$ & $=0.046$ \\
\hline Arm compactness index $\left(\mathrm{A}_{\mathrm{Cl}}\right)$ & $0.043 \pm 0.0$ & $0.044 \pm 0.0$ & $=0.806$ \\
\hline Leg compactness index $\left(\mathrm{L}_{\mathrm{Cl}}\right)$ & $0.071 \pm 0.01$ & $0.076 \pm 0.01$ & $=0.358$ \\
\hline Carcass compactness index $\left(\mathrm{C}_{\mathrm{CI}}\right)$ & $0.30 \pm 0.05^{\mathrm{b}}$ & $0.36 \pm 0.07^{\mathrm{a}}$ & $=0.045$ \\
\hline Carcass economic index $\left(\mathrm{C}_{\mathrm{EI}}\right)$ & $18.8 \pm 0.51$ & $19.3 \pm 0.59$ & $=0.066$ \\
\hline
\end{tabular}

ab Different letters in the same columns indicate significant differences by the Tukey test $(P<0.05)$.

\section{Table 2.}

Mean and standard deviation of productive and physical-chemical characteristics of the carcass, commercial cuts and yields of cuts in the Morada Nova red breed lambs $\left(\mathrm{M}_{\mathrm{NR}}\right)$ and crossbred with the white $\left(M_{N} F_{1}\right)$ 


\begin{tabular}{|c|c|c|c|}
\hline \multirow[t]{2}{*}{ Variables } & \multicolumn{2}{|c|}{ Genetic groups } & \multirow[t]{2}{*}{$P$-Valor } \\
\hline & $M_{N} R$ & $\mathrm{M}_{\mathrm{N}} \mathrm{F}_{1}$ & \\
\hline Age at slaughter (days) $)^{¥}$ & $111.8 \pm 4.2$ & $113.4 \pm 6.0$ & 0.500 \\
\hline Shrunk body weight $(\mathrm{kg}) \stackrel{*}{ }$ & $26.3 \pm 4.3 b$ & $31.0 \pm 4.3 a$ & 0.028 \\
\hline \multicolumn{4}{|l|}{ Productive and physicochemical of carcass } \\
\hline Hot carcass weigth $\left(\mathrm{H}_{\mathrm{Cw}} ; \mathrm{kg}\right)^{¥}$ & $13.0 \pm 2.2 \mathrm{~b}$ & $15.6 \pm 2.3^{a}$ & $=0.021$ \\
\hline Cold carcass weigth $\left(\mathrm{C}_{\mathrm{CW}} ; \mathrm{kg}\right)^{¥}$ & $12.9 \pm 2.2$ & $15.2 \pm 2.6$ & $=0.052$ \\
\hline Right half of the carcass weight $\left(\mathrm{R}_{\mathrm{HCw}} ; \mathrm{kg}\right)^{¥}$ & $6.1 \pm 0.9 b$ & $7.2 \pm 1.1^{\mathrm{a}}$ & $=0.031$ \\
\hline Hot carcass yield $\left(\mathrm{H}_{\mathrm{CY} ; \%}\right)^{¥}$ & $49.6 \pm 1.6$ & $50.5 \pm 1.7$ & $=0.231$ \\
\hline Loin eye area $\left(L_{E A} ; \mathrm{cm}^{2}\right)^{¥}$ & $9.86 \pm 1.3 b$ & $11.54 \pm 1.7^{a}$ & $=0.028$ \\
\hline Subcutaneous fat thickness $\left(\mathrm{S}_{\mathrm{FT}} ; \mathrm{mm}\right)^{¥}$ & $1.33 \pm 0.19$ & $1.24 \pm 0.34$ & $=0.504$ \\
\hline Cooling weight loss $\left(\mathrm{C}_{\mathrm{WL}} ; \%\right)^{¥}$ & $7.9 \pm 1.3$ & $6.7 \pm 1.2$ & $=0.055$ \\
\hline \multicolumn{4}{|l|}{ pH: } \\
\hline 0 hour after slaughter $¥$ & $6.7 \pm 0.18$ & $6.9 \pm 0.25$ & $=0.130$ \\
\hline 24 hours after slaughter $¥$ & $6.0 \pm 0.13$ & $6.1 \pm 0.25$ & $=0.117$ \\
\hline \multicolumn{4}{|l|}{ Carcass temperature } \\
\hline Initial $\left(\mathrm{I}_{T} ; \mathrm{i} \mathrm{C}\right)^{¥}$ & $31.1 \pm 3.2$ & $29.2 \pm 1.0$ & $=0.100$ \\
\hline Final $\left(\mathrm{F}_{\mathrm{T}} ;{ }^{\circ} \mathrm{C}\right)^{¥}$ & $6.9 \pm 0.6$ & $6.3 \pm 0.9$ & $=0.131$ \\
\hline \multicolumn{4}{|l|}{ Commercial cuts: Weight (kg) } \\
\hline Leg ${ }^{*}$ & $1.94 \pm 0.35$ & $2.20 \pm 0.34$ & $=0.116$ \\
\hline Shoulder ${ }^{*}$ & $1.01 \pm 0.16$ & $1.16 \pm 0.25$ & $=0.141$ \\
\hline $\operatorname{Rib}^{*}$ & $0.59 \pm 0.07 b$ & $0.72 \pm 0.11 \mathrm{a}$ & $=0.006$ \\
\hline Loin $¥$ & $0.59 \pm 0.09 b$ & $0.71 \pm 0.10 \mathrm{a}$ & $=0.015$ \\
\hline Breast ${ }^{*}$ & $1.49 \pm 0.32 b$ & $1.83 \pm 0.27 \mathrm{a}$ & $=0.023$ \\
\hline Neck $^{¥}$ & $0.46 \pm 0.12$ & $0.55 \pm 0.13$ & $=0.124$ \\
\hline
\end{tabular}




\begin{tabular}{|c|c|c|c|}
\hline \multicolumn{4}{|l|}{ Yields (\%) } \\
\hline Leg $^{¥}$ & $31.8 \pm 0.97$ & $30.6 \pm 1.79$ & $=0.092$ \\
\hline Shoulder $¥$ & $16.73 \pm 2.32$ & $16.09 \pm 1.87$ & $=0.508$ \\
\hline $\operatorname{Rib}^{*}$ & $9.82 \pm 1.15$ & $10.08 \pm 0.55$ & $=0.523$ \\
\hline Loin $¥$ & $9.71 \pm 0.89$ & $9.95 \pm 0.89$ & $=0.567$ \\
\hline Breast $^{*}$ & $24.38 \pm 2.89$ & $25.48 \pm 1.10$ & $=0.280$ \\
\hline Neck ${ }^{*}$ & $7.52 \pm 1.10$ & $7.72 \pm 1.05$ & $=0.688$ \\
\hline \multicolumn{4}{|c|}{ Medidas qualitativas da carcaça ${ }^{\mathbb{Z}}$} \\
\hline Finish ${ }^{H}$ & $2.50-0.63$ & $2.50-1.00$ & $=0.628$ \\
\hline Conformation ${ }^{H}$ & $2.50-0.75$ & $3.25-0.63$ & $=0.350$ \\
\hline Perirenal fat $\left(\mathrm{P}_{\mathrm{F}}\right)^{H}$ & $2.50-0.63$ & $2.50-0.63$ & $=0.999$ \\
\hline
\end{tabular}

$¥ \mathrm{ab}$ Different letters on the same columns indicate significant differences by Tukey’s test $(P<0.05)$.

${ }^{H}$ Different same on the same columns indicate significant differences by Kruskal-Wallis test $(P<0.05)$.

${ }^{\mathbb{R}}$ Resultados apresentados para esse grupo de variável é mediana - intervalo interquartil (IQR)

\section{Table 3}

Canonical discriminant analysis for carcass characteristics, morphometry and zoometric indices in Morada Nova red breed lambs $\left(M_{N R}\right)$ and crossbred with the white $\left(M_{N} F_{1}\right)$ 


\begin{tabular}{|c|c|c|c|c|c|c|}
\hline \multirow{2}{*}{$\begin{array}{l}\text { Group of } \\
\text { discriminating } \\
\text { variables }\end{array}$} & \multirow{2}{*}{$\begin{array}{l}\mathrm{C}_{\mathrm{CC}} \\
1 \\
(\%)\end{array}$} & \multicolumn{2}{|c|}{$\begin{array}{l}\text { Classification by } \\
\text { genetic group }{ }^{2}(\%)\end{array}$} & $\begin{array}{l}\text { Variance } \\
\text { Explained } \\
(\%)\end{array}$ & $\begin{array}{l}\text { Lambda } \\
\text { de Wilks }\end{array}$ & $\begin{array}{l}\text { Main } \\
\text { Traits }^{4}\end{array}$ \\
\hline & & $\mathrm{MN}_{\mathrm{RED}}$ & $\mathrm{M}_{\mathrm{N}} \mathrm{F}_{1}$ & $\mathrm{~F}_{\mathrm{C} 1}$ & $\mathrm{~F}_{\mathrm{C} 1}$ & $\mathrm{FC}_{1}$ \\
\hline Body morphometry & 91.3 & 90.9 & 91.7 & 100 & 0.008 & $\begin{array}{l}C_{H} \cdot C_{G} \\
C_{W} \cdot R_{H}\end{array}$ \\
\hline Zoometric index & 95.7 & 90.9 & 100.0 & 100 & 0.023 & $\begin{array}{l}B_{\mid} \cdot T_{P R l} \cdot \\
A_{1} \cdot T_{B l}\end{array}$ \\
\hline $\begin{array}{l}\text { Evaluation of } \\
\text { carcass and muscle }\end{array}$ & 65.2 & 81.8 & 50.0 & 100 & 0.049 & $\mathrm{~L}_{\mathrm{EA}} \cdot \mathrm{P}_{\mathrm{F}}$ \\
\hline $\begin{array}{l}\text { Carcass } \\
\text { morphometric }\end{array}$ & 73.9 & 63.6 & 83.3 & 100 & 0.013 & $\mathrm{C}_{\mathrm{GC}}$ \\
\hline Carcass index & 56.5 & 63.6 & 50.0 & 100 & 0.045 & $\mathrm{C}_{\mathrm{Cl}}$ \\
\hline $\begin{array}{l}\text { Performance and } \\
\text { carcass }\end{array}$ & 60.9 & 54.5 & 66.7 & 100 & 0.021 & $\mathrm{H}_{\mathrm{CW}}$ \\
\hline $\begin{array}{l}\text { Commercial cuts } \\
(\mathrm{kg})\end{array}$ & 65.2 & 72.7 & 58.3 & 100 & 0.022 & Rib; Loin \\
\hline Cut yield (\%) & 69.6 & 81.8 & 58.3 & 100 & 0.092 & Leg Y. \\
\hline Mix of variables & 87.0 & 90.9 & 83.3 & 100 & 0.027 & $\begin{array}{l}T_{B \mid} \cdot \text { Leg } \\
\text { Y.. } C_{G} \cdot \text { Rib }\end{array}$ \\
\hline
\end{tabular}

${ }^{1}$ Total percentage of cases correctly classified: $\mathrm{C}_{\mathrm{CC}}=$ cases correctly classified.

${ }^{2}$ Percentage of cases correctly classified by genetic group.

${ }^{3}$ Statistic test: Canonical functions $\left(F_{\mathrm{C} 1}\right)$ with $P<0.05$ of Wilks' Lambda were considered significant.

${ }^{4}$ Main traits of the groups: $C_{H}=$ chest height; $C_{G}=$ chest girth; $C_{W}=$ chest width; $R_{H}=$ rump height; $B_{I}=$ body index; $T_{P R I}=$ thoracic perimeter relation index; $A_{l}=$ anamorphosis index; $T_{B I}=$ thoracic body index; $L_{E A}=$ loin eye area; $P_{F}=$ perirenal fat; $C_{G C}=$ carcass chest girth; $C_{C I}=$ carcass compactness index; $H_{C W}=$ hot carcass weight; Leg Y. = leg yield

Table 4. Factor analysis for carcass productive characteristics, morphometry and zoometric indices in Morada Nova lambs. 


\begin{tabular}{|c|c|c|c|c|c|}
\hline \multirow[t]{2}{*}{ Variables } & \multicolumn{4}{|l|}{ Factors1 } & \multirow[t]{2}{*}{ Commonality } \\
\hline & $\begin{array}{l}\text { Morpho - } \\
\text { Economic } \\
\text { (1) }\end{array}$ & $\begin{array}{l}\text { Morpho - } \\
\text { Productive } \\
\text { (2) }\end{array}$ & $\begin{array}{l}\text { Morpho } \\
\text { commercial } \\
\text { (3) }\end{array}$ & $\begin{array}{l}\text { Equilibrium } \\
\text { (4) }\end{array}$ & \\
\hline $\begin{array}{l}\text { Carcass } \\
\text { compactness index } \\
\left(\mathrm{C}_{\mathrm{Cl}}\right)\end{array}$ & 0.809 & -0.252 & -0.093 & -0.022 & 0.727 \\
\hline Loin eye area $\left(L_{E A}\right)$ & 0.789 & -0.235 & -0.108 & 0.408 & 0.819 \\
\hline $\begin{array}{l}\text { Hot carcass yield } \\
\left(\mathrm{H}_{\mathrm{CY}}\right)\end{array}$ & 0.318 & 0.659 & 0.572 & 0.042 & 0.865 \\
\hline $\begin{array}{l}\text { Cooling weight loss } \\
\left(\mathrm{C}_{\mathrm{WL}}\right)\end{array}$ & -0.914 & 0.155 & -0.280 & 0.037 & 0.940 \\
\hline Leg yield (Leg Y) & -0.131 & 0.205 & 0.589 & -0.627 & 0.800 \\
\hline Rump height $\left(\mathrm{R}_{\mathrm{H}}\right)$ & 0.878 & -0.287 & 0.025 & -0.149 & 0.877 \\
\hline Chest height $\left(\mathrm{C}_{\mathrm{H}}\right)$ & 0.759 & -0.149 & 0.233 & 0.354 & 0.778 \\
\hline Chest girth $\left(\mathrm{C}_{\mathrm{G}}\right)$ & 0.649 & -0.433 & -0.143 & -0.458 & 0.839 \\
\hline Chest width $\left(\mathrm{C}_{\mathrm{W}}\right)$ & 0.905 & 0.030 & -0.141 & -0.096 & 0.849 \\
\hline Body index $\left(B_{I}\right)$ & -0.480 & -0.424 & 0.550 & 0.383 & 0.860 \\
\hline $\begin{array}{l}\text { Thoracic perimeter } \\
\text { relation index }\left(T_{P R I}\right)\end{array}$ & -0.001 & 0.876 & -0.386 & 0.090 & 0.925 \\
\hline $\begin{array}{l}\text { Anamorphosis index } \\
\left(A_{1}\right)\end{array}$ & 0.771 & 0.494 & -0.339 & -0.018 & 0.954 \\
\hline $\begin{array}{l}\text { Carcass economic } \\
\text { index }\left(C_{E I}\right)\end{array}$ & 0.677 & 0.452 & 0.512 & 0.114 & 0.938 \\
\hline Partial variance. \% & 38.50 & 18.80 & 17.50 & 11.00 & - \\
\hline Total variance & 38.50 & 57.30 & 74.80 & 85.90 & - \\
\hline
\end{tabular}

${ }^{1}$ Factor loads in bold indicate greater participation of the variable in the respective factor.

\section{Figures}




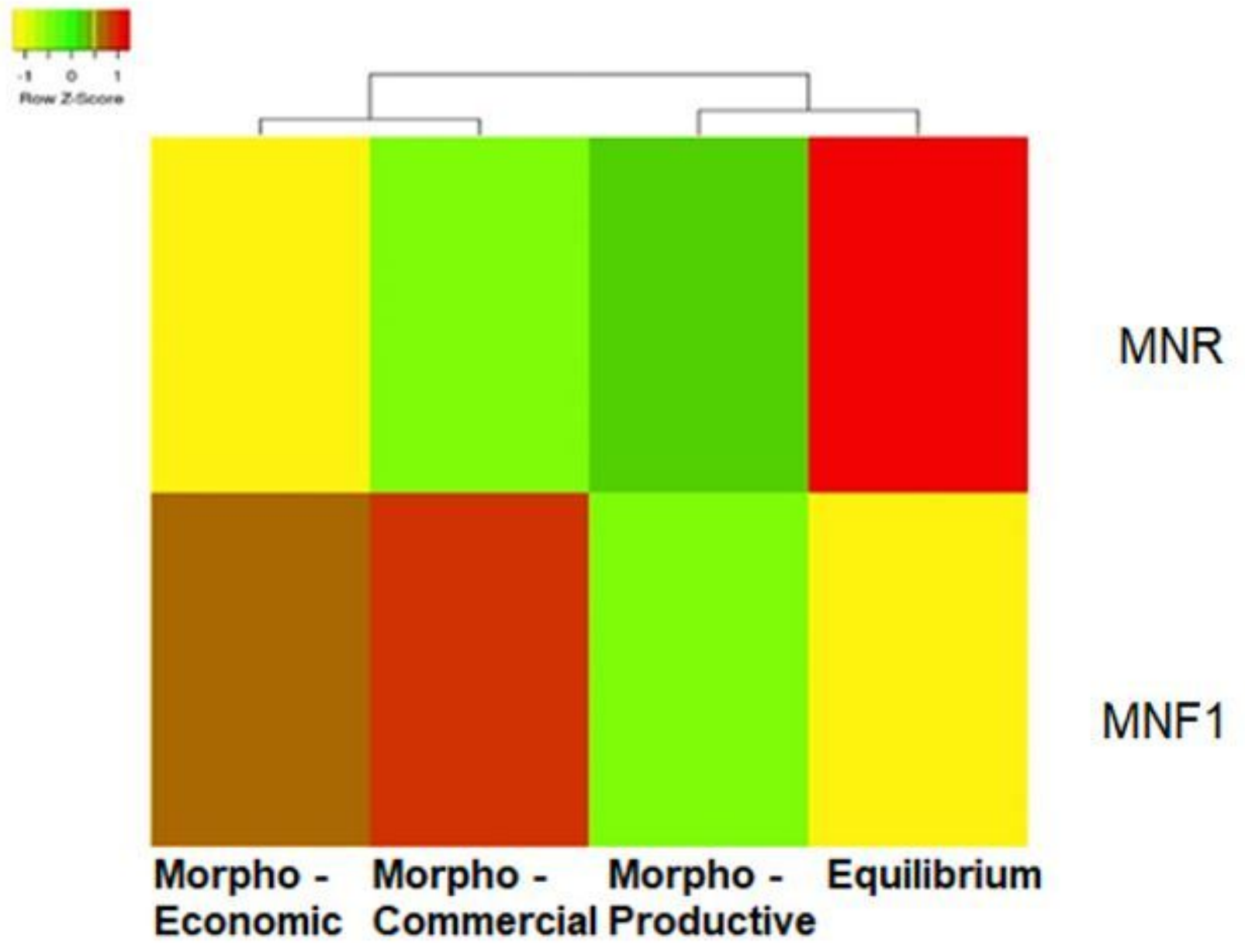

\section{Figure 1}

Heat map of the main components for productive carcass characteristics, morphometry and zoomometric indexes in Morada Nova breed red lambs (MNR) and crossbred with the white (MNF1). Note: Positive Z-score values show a positive association between genetic groups (lines) and factors 


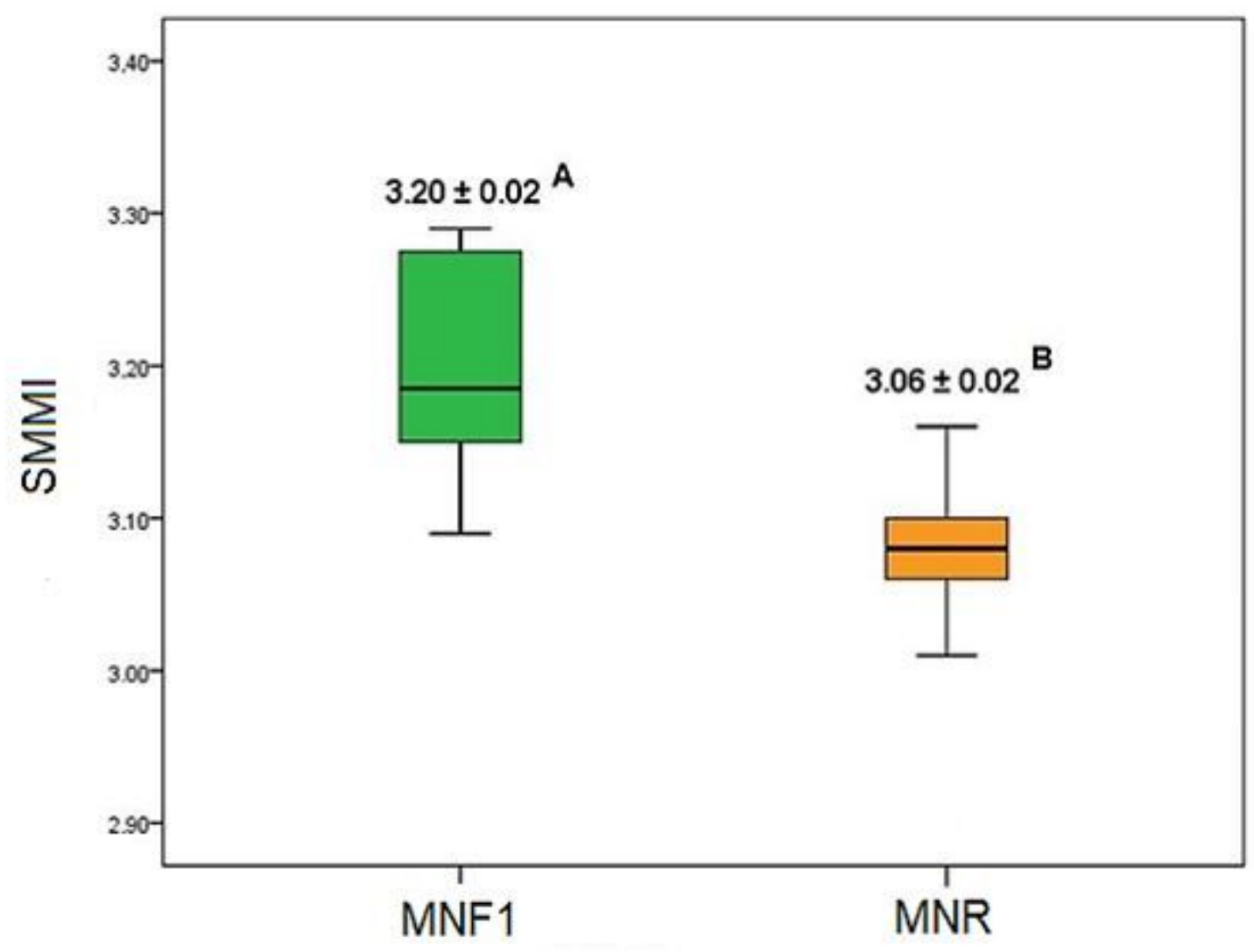

Genetic groups

Figure 2

Boxplot of Sheep Meat Morphometric Index (SMMI) of the Morada Nova breed red (MNR) and crossbed with the white (MNF1). Note: Means followed by different letters are statistically different by the Tukey test $(P<0.001)$. 